\title{
Gene transcripts encoding hypoxia-inducible factor (HIF) exhibit tissue- and muscle fiber type-dependent responses to hypoxia and hypercapnic hypoxia in the Atlantic blue crab, Callinectes sapidus
}

\author{
Kristin M. Hardy ～， Chandler R. Follett , Louis E. Burnett ， Sean C. Lema
}

\begin{abstract}
A B S T R A C T
Hypoxia inducible factor (HIF) is a transcription factor that under low environmental oxygen regulates the expression of suites of genes involved in metabolism, angiogenesis, erythropoiesis, immune function, and growth. Here, we isolated and sequenced partial cDNAs encoding hif- $\alpha$ and arnt/hif- $\beta$ from the Atlantic blue crab, Callinectes sapidus, an estuarine species that frequently encounters concurrent hypoxia $\left(\right.$ low $\left.\mathrm{O}_{2}\right)$ and hypercapnia (elevated $\left.\mathrm{CO}_{2}\right)$. We then examined the effects of acute exposure $(1 \mathrm{~h})$ to hypoxia $(\mathrm{H})$ and hypercapnic hypoxia (HH) on relative transcript abundance for hif- $\alpha$ and arnt/hif- $\beta$ in different tissues (glycolytic muscle, oxidative muscle, hepatopancreas, gill, and gonads) using quantitative real-time RT-PCR. Our results indicate that hif- $\alpha$ and arnt/hif- $\beta$ mRNAs were constitutively present under well-aerated normoxia (N) conditions in all tissues examined. Further, $\mathrm{H}$ and $\mathrm{HH}$ exposure resulted in both tissue-specific and muscle fiber type-specific effects on relative hif- $\alpha$ transcript abundance. In the gill and glycolytic muscle, relative hif- $\alpha$ mRNA levels were significantly lower under $\mathrm{H}$ and $\mathrm{HH}$, compared to $\mathrm{N}$, while no change (or a slight increase) was detected in oxidative muscle, hepatopancreas and gonadal tissues. $\mathrm{H}$ and $\mathrm{HH}$ did not affect relative transcript abundance for arnt/hif- $\beta$ in any tissue or muscle fiber type. Thus, in crustaceans the HIF response to $\mathrm{H}$ and $\mathrm{HH}$ appears to involve changes in hif transcript abundance, with variation in hif- $\alpha$ and arnt/hif- $\beta$ transcriptional dynamics occurring in both a tissue- and muscle fiber type-dependent manner.
\end{abstract}

\section{Introduction}

Eutrophication-induced hypoxia (low dissolved oxygen; $<2 \mathrm{mg} \mathrm{l}^{-1}$ ) is among the most severe and persistent threats to the health of coastal estuaries and marine ecosystems (Goldberg, 1995; Diaz, 2001; Wu, 2002; Diaz and Rosenberg, 2008). As human population densities increase in coastal areas, the anthropogenic input of nutrients and organic matter into coastal waters has resulted in hypoxic and anoxic (complete absence of dissolved oxygen) events of increasing magnitude, frequency and duration (Diaz and Rosenberg, 1995, 2008; Diaz, 2001). These environmental hypoxia events almost always occur in concert with elevated carbon dioxide levels (hypercapnia) - a condition resulting from increased respiration - which leads to reduced water $\mathrm{pH}$ (Cochran and
Burnett, 1996; Burnett, 1997; Melzner et al., in press), and consequently reduced internal $\mathrm{pH}$ (acidosis). As global climate change progresses, the frequency and duration of hypoxia and hypercapnia events in coastal waters are predicted to intensify, which will have significant ramifications for the physiological status and survival of countless marine species.

The detrimental effects of low dissolved oxygen conditions in these coastal waters are most obvious in the catastrophic mortality events that occur in hypoxic 'dead zones' (Garlo et al., 1979; Winn and Knott, 1992; Lenihan and Peterson, 1998). However, sub-lethal hypoxia can trigger a suite of behavioral, physiological, biochemical and genetic responses in marine organisms that can severely reduce overall fitness (Burnett, 1997; Burnett and Stickle, 2001). In crustaceans and fish, for example, hypoxia reduces feeding (Bell et al., 2003), depresses immune function (Le Moullac et al., 1998; Mikulski et al., 2000; Cheng et al., 2002; Holman et al., 2004; Burgents et al., 2005; Tanner et al., 2006; de la Vega et al., 2007; Paschke et al., 2010), limits growth (Stewart et al., 1967; Whitworth, 1968; Seidman and Lawrence, 1985; Das and Stickle, 1993; Thetmeyer et al., 1999; Coiro et al., 2000; Stierhoff et al., 2006), impairs reproductive function (Brown-Peterson et al., 2008; Thomas and Rahman, 2009), and disrupts sexual differentiation and 
reproductive hormone levels (Shang et al., 2006; Cheung, 2008; Thomas and Rahman, 2009). Hypercapnia alone is also known to alter physiological function, particularly respiratory function (Cochran and Burnett, 1996). And yet, the combined effects of hypercapnic hypoxia $(\mathrm{HH})$ have received comparatively little attention to date, so much remains unknown about the molecular and cellular mechanisms by which organisms cope with low $\mathrm{O}_{2}$ conditions in combination with elevated $\mathrm{CO}_{2}$.

Hypoxia inducible factors (HIFs) are a family of highly conserved transcription factors that act as global regulators of oxygen homeostasis and the adaptive response to oxygen deprivation (Semenza, 1999). The functional HIF protein is a heterodimeric DNA-binding complex comprising a HIF- $\alpha$ subunit and a HIF- $\beta$ (also called the aryl hydrocarbon receptor nuclear translocator, or ARNT) subunit, both of which are basic helix-loop-helix/Per-Arnt-Sim (bHLH/PAS) proteins. The $\alpha$ and $\beta$ subunits of HIF are each constitutively expressed in cells; however, under normoxic conditions, HIF- $\alpha$ is selectively tagged for proteosomal degradation (Salceda and Caro, 1997; Maxwell et al., 1999) so that appreciable levels are only found under hypoxia. In low oxygen conditions, HIF- $\alpha$ is translocated into the nucleus where it heterodimerizes with HIF- $\beta$ and binds to hypoxia-response elements (HRE) found on specific target genes. In mammalian systems, hypoxia-inducible target genes are primarily involved in angiogenesis, erythropoiesis, glucose transport and anaerobic glycolysis (Wenger, 2000; Wu, 2002; Gorr et al., 2006; see Wenger et al., 2005 for review), processes that are integral to enhancing tissue oxygenation and glycolytic energy production.

While the dynamics of HIF and its functional responses have been best studied in mammals, genes homologous to those in the mammalian HIF signaling pathway are also found in fish (Soitamo et al., 2001; Thomas and Rahman, 2009), amphibians (de Beaucourt and Coumailleau, 2007), birds (Catron et al., 2001), and invertebrates (Soñanez-Organis et al., 2009). However, our knowledge of the molecular responses to hypoxia in these other animal systems is comparatively limited. The hypoxia-mediated response of the hif genes has been investigated in Pacific white shrimp (Soñanez-Organis et al., 2009), grass shrimp (Li and Brouwer, 2007) and Eastern oyster (Piontkivska et al., 2011). Otherwise though, very little is known about the transcriptional dynamics and expression of genes encoding HIF among marine organisms in particular, despite the fact that these organisms can be subject to fluctuating oxygen conditions on a daily, seasonal and spatial basis. For instance, the Atlantic blue crab (Callinectes sapidus) is an estuarine species that frequently encounters episodes of hypercapnic hypoxia and is well known for its ability to tolerate and respond to variable oxygen conditions (Burnett, 1997). This characteristic makes $C$. sapidus an excellent marine organism in which to study the molecular response to hypercapnic hypoxia. Further, as a species of considerable economic worth [C. sapidus landings in the Gulf of Mexico alone averaged $\$ 202,000,000$ (USD) annually between 2000 and 2005 (McCrea-Strub et al., 2011)], the value of investigating the impacts of an increasingly hypercapnic and hypoxic estuary environment in this species should be immediately obvious.

In the present study, we isolated and sequenced cDNAs encoding the HIF- $\alpha$ and HIF- $\beta$ protein subunits from $C$. sapidus, and examined the effects of acute $(1 \mathrm{~h})$ exposure to hypoxia $(\mathrm{H})$ and hypercapnic hypoxia $(\mathrm{HH})$ on relative transcript abundance of hif- $\alpha$ and hif- $\beta$ (hereafter referred to as arnt/hif- $\beta$ ) genes in the hepatopancreas, gill, gonad, and muscle tissues of both male and female crabs. Based on the picture of HIF transcriptional regulation that has emerged from studies in vertebrates, we hypothesized that $\mathrm{H}$ and $\mathrm{HH}$ exposure each would lead to a significant increase in hif- $\alpha$ levels, but would have no corresponding effect on arnt/hif- $\beta$ levels. Additionally, we compared the effect of hypoxia and hypercapnic hypoxia on relative levels of hif subunit mRNAs between aerobic dark fibers and anaerobic light fibers of the skeletal muscle, with the aim of discerning potential differences in hif- $\alpha$ and arnt gene expression between two metabolically distinct muscle fiber types. Aerobic dark fibers are characterized by using oxidative metabolic processes to power sustained, endurance contractions, whereas anaerobic light fibers use only glycolytic processes to power burst-escape contractions. The dramatic differences in cellular oxygen demand between these muscle fiber types led us to hypothesize that patterns of hif- $\alpha$ and arnt/hif- $\beta$ gene transcript abundance under normal oxygen conditions (normoxia) - and in response to hypoxia and hypercapnic hypoxia - would differ between the two fibers.

\section{Materials and methods}

\subsection{Animal care and maintenance}

Adult Atlantic blue crabs, $C$. sapidus Rathbun, were collected in the tidal creeks surrounding Charleston Harbor (Charleston, SC, USA) or were purchased from local commercial seafood vendors. Animals were maintained in aerated, recirculating, UV-sterilized seawater (30 ppt salinity, $23-25^{\circ} \mathrm{C}$ ) under a $12 \mathrm{~h}: 12 \mathrm{~h}$ light:dark photoperiod and fed frozen bait squid on alternating days. Animals were held in these conditions for a minimum of one week and only those animals in the intermolt stage, as determined by visual examination of the cuticle layer in the fifth pereiopod, were considered acceptable for use. Mean body mass \pm SEM for male and female crabs $(n=8-14$ per treatment group) was $169.94 \pm 5.60 \mathrm{~g}$ and $162.41 \pm 3.27 \mathrm{~g}$, respectively.

\subsection{Experimental gas exposures}

The day following a final feeding, individual animals were transferred from their holding tanks into a $38 \mathrm{~L}$ exposure tank containing UVsterilized seawater ( $30 \mathrm{ppt}$ and $25^{\circ} \mathrm{C}$ ) and held for $24 \mathrm{~h}$. Subsequently, animals were exposed to one of the following dissolved gas treatments: normoxia $\left(\mathrm{N} ; \mathrm{Po}_{2}=20.0 \mathrm{kPa}, P_{\mathrm{CO} 2}<0.06 \mathrm{kPa}, \mathrm{pH}=7.8-8.0\right)$, hypoxia $\left(\mathrm{H} ; \mathrm{Po}_{2}=4.0 \mathrm{kPa}, P_{\mathrm{CO} 2}<0.06 \mathrm{kPa}, \mathrm{pH}=7.8-8.0\right)$, or hypercapnic hypoxia $\left(\mathrm{HH} ; \mathrm{Po}_{2}=4.0 \mathrm{kPa}, P_{\mathrm{CO} 2}=1.8 \mathrm{kPa}, \mathrm{pH}=6.7-7.0\right)$. Hypoxia was achieved by bubbling pure nitrogen gas into the exposure tank, while hypercapnic hypoxia was achieved by bubbling a mixture of $98 \%$ nitrogen and $2 \%$ carbon dioxide gas produced with a mechanical gas mixer (H. Wösthoff, Bochum, Germany). Normoxic conditions were maintained by simply bubbling with atmospheric air. Throughout each exposure, the $\mathrm{Po}_{2}$ was monitored and regulated using an oxygen electrode (YSI Model 58, Yellow Springs, OH, USA) and data acquisition system (Sable Systems International, Las Vegas, NV, USA) as described by Mikulski et al. (2000). Animals (one individual per tank) were held in these treatments for $1 \mathrm{~h}$ and promptly sacrificed. Skeletal muscle (anaerobic light and aerobic dark), hepatopancreas, gill and gonad tissues were excised and immediately flash-frozen in liquid nitrogen. Care was taken to collect tissues at approximately $14: 00 \mathrm{~h}$ each day to control for circadian rhythms in gene expression.

\subsection{Identification and sequencing of $c D N A$ for hif- $\alpha$ and arnt/hif- $\beta$}

\subsection{1. $R N A$ isolation and reverse transcription}

Total RNA was extracted from the eyestalk of a male blue crab using TriReagent (Molecular Research Center, Cincinnati, OH, USA) with bromochloropropane as the phase separation reagent. Extracted RNA was then DNase I treated (Turbo DNA-free, Ambion, Austin, TX, USA) and quantified by spectrophotometry (260:280 ratio of 1.99 ; NanoDrop 2000, ThermoScientific, Wilmington, DE, USA), before being examined on a $0.8 \%$ agarose gel for RNA quality.

First strand cDNA was synthesized in a $20 \mu \mathrm{L}$ reverse transcription reaction by incubating $5 \mu \mathrm{g}$ of total RNA template $(4.75 \mu \mathrm{L})$ with $1.0 \mu \mathrm{L}$ annealing buffer, $1.0 \mu \mathrm{L}$ of random primers (Promega, Madison, WI, USA), and $1.25 \mu \mathrm{L}$ of RNase-free $\mathrm{H}_{2} \mathrm{O}$ (Sigma-Aldrich, St. Louis, MO, USA) at $65^{\circ} \mathrm{C}$ for $5 \mathrm{~min}$. Subsequently, $10 \mu \mathrm{L}$ of $5 \times$ buffer and $2 \mu \mathrm{L}$ of Superscript III Reverse Transcriptase Enzyme Supermix 
(Invitrogen) were added, and the mixture was incubated under a thermal profile of $25^{\circ} \mathrm{C}$ for $10 \mathrm{~min}$ followed by $50{ }^{\circ} \mathrm{C}$ for $50 \mathrm{~min}$ and $85^{\circ} \mathrm{C}$ for $5 \mathrm{~min}$ (iCycler, BioRad).

\subsubsection{Isolation and sequencing of partial arnt/hif- $\beta c D N A$}

PCR was performed using three nested sets of degenerate primers designed to consensus regions of cDNA sequences for arnt/hif- $\beta$ described previously in Pacific whiteleg shrimp (Litopenaeus vannamei; GenBank accession no. ACU30155; Soñanez-Organis et al., 2009), jewel wasp (Nasonia vitripennis, XP_001605013), and zebrafish (Danio rerio; type 1a; AY707649). The outer-nested primers were (forward) 5'CAGGACAAGGAG(A,C)GATTTGCCAG-3' and (reverse) 5'-TCATGCGGCA $(\mathrm{A}, \mathrm{G}) \mathrm{ATGAA}(\mathrm{A}, \mathrm{T}) \mathrm{CC}(\mathrm{A}, \mathrm{T}) \mathrm{CGT}-3^{\prime}$, the middle-nested primers were (forward) 5'-AGAACCAC(A,T)GCGAGATCGAGCG-3' and (reverse) 5'-CGA(A, $\mathrm{G}) \mathrm{CCC}(\mathrm{A}, \mathrm{G}) \mathrm{TGCACAG}(\mathrm{G}, \mathrm{T}) \mathrm{C}(\mathrm{G}, \mathrm{T})(\mathrm{A}, \mathrm{C}) \mathrm{A}-\mathrm{3}^{\prime}$, and the inner-nested primers used were (forward) $5^{\prime}-\mathrm{GA}(\mathrm{C}, \mathrm{T})$ ATGGTGCCC(A,G)CCTGC-3' and (reverse) $5^{\prime}$-TTCTT(A,G)AC(A,G)GT(G,T)CCGGTCTTGAGAT-3'.

First-strand cDNA was amplified in $50 \mu \mathrm{L}$ PCR reactions containing $2 \mu \mathrm{L}$ of reverse-transcribed cDNA, $25 \mu \mathrm{L}$ GoTaq Master Mix (Promega, Madison, WI, USA), $21 \mu \mathrm{L}$ RNase-free $\mathrm{H}_{2} 0$, and $1 \mu \mathrm{L}$ each of forward and reverse primer $(50 \mu \mathrm{M})$ under a thermal profile of $95{ }^{\circ} \mathrm{C}$ for 2 min followed by 35 cycles of $95{ }^{\circ} \mathrm{C}$ for $30 \mathrm{~s}, 50-51{ }^{\circ} \mathrm{C}$ for $30 \mathrm{~s}$, and $72{ }^{\circ} \mathrm{C}$ for $1 \mathrm{~min}$, and ending with $72{ }^{\circ} \mathrm{C}$ for 5 min on a PT-100 Thermal Cycler (MJ Research). When electrophoresis of the PCR product on a $1.2 \%$ agarose gel revealed a band of predicted size, the CDNA was purified (QIAquick PCR Purification Kit, Qiagen, Inc., Valencia, CA, USA) and sequenced by MacrogenUSA (Rockville, MD, USA) on an ABI Prism 3100 Genetic Analyzer using ABI Big Dye Terminator Cycle Sequencing Kit 3.1. A consensus sequence encoding a 422 bp nucleotide partial length cDNA for arnt/hif- $\beta$ was assembled using Sequencher ${ }^{\mathrm{TM}}$ v.4.8 (Gene Codes Corp., Ann Arbor, MI, USA).

2.3.3. Extension of initial partial cDNA sequences for hif- $\alpha$ and arnt/hif- $\beta$

Nested gene-specific primers for arnt/hif- $\beta$ were designed to the 422 bp nucleotide partial cDNA sequence obtained above. These primers were then used to extend the partial cDNA sequences by 5'- and 3'-rapid amplification of cDNA ends (BD SMARTer RACE cDNA Amplification Kit, Clontech Laboratories, Inc., Mountain View, CA). Gene-specific primers for the RACE reactions are provided as part of the accompanying on-line Supplemental materials (Table 1). First strand cDNA was amplified in $50 \mu \mathrm{L}$ reactions containing reverse-transcribed cDNA from the gills of a male blue crab using the following reaction components: $5 \mu \mathrm{L}$ of $10 \times$ High Fidelity PCR Buffer, $2 \mu \mathrm{L}$ of $\mathrm{MgSO}_{4}(50 \mathrm{mM}), 1 \mu \mathrm{L}$ of dNTPs $(10 \mathrm{mM})$, and $0.2 \mu \mathrm{L}$ of Platinum ${ }^{\circledR}$ Taq High Fidelity Polymerase (Invitrogen, Inc.), along with $3 \mu \mathrm{L}$ of cDNA template. Amplification occurred under a thermal profile of 5 cycles of $94{ }^{\circ} \mathrm{C}$ for $30 \mathrm{~s}$ followed by $72{ }^{\circ} \mathrm{C}$ for 2 min; 5 cycles of $94^{\circ} \mathrm{C}$ for $30 \mathrm{~s}, 70{ }^{\circ} \mathrm{C}$ for $30 \mathrm{~s}$, and $72{ }^{\circ} \mathrm{C}$ for $2 \mathrm{~min}$, and then 25 cycles of $94{ }^{\circ} \mathrm{C}$ for $30 \mathrm{~s}, 68^{\circ} \mathrm{C}$ for $30 \mathrm{~s}$, and $72{ }^{\circ} \mathrm{C}$ for $2 \mathrm{~min}$. When electrophoresis of the $5^{\prime}$ - and $3^{\prime}$-RACE products on $1.2 \%$ agarose gels failed to reveal any clear PCR product bands, the nested gene-specific primers were used in a second PCR reaction. PCR products from all resulting bands were purified (QIAquick PCR Purification Kit) and sequenced (MacrogenUSA). The resulting cDNA sequences were aligned using Sequencher ${ }^{\mathrm{TM}}$ v.4.8 software and compared against sequences for arnt/hif- $\beta$ from vertebrates and other invertebrates using BLAST.

In addition, a previously published partial cDNA of $1491 \mathrm{bp}$ nucleotides encoding hif- $\alpha$ from blue crab (GenBank accession no. EF568606) was extended using a nested set of gene-specific primers. The primers were designed using Primer Express 2.0 software (Applied Biosystems, Inc.) and were the following: outer forward, $5^{\prime}-$ GTGAGATTTTCGCTGAGCTGGC-3'; inner forward, 5'-CTGGACAAAGCCTCCATCATGA-3'; inner reverse, 5'-TGTCCGTGGCACAAAGATCTT-3'; and outer reverse, $5^{\prime}$-ATACATGAGTCCCCCTCCAGGT- $3^{\prime}$. These primers amplified a 1362 bp nucleotide partial cDNA from blue crab, which was then sequenced (MacrogenUSA) to confirm its identity as hif- $\alpha$.
Nested gene-specific primers for RACE PCR were subsequently designed to this partial cDNA (on-line Supplemental materials, Table 1), and used in 5'- and 3'-RACE reactions to extend this partial cDNA of hif- $\alpha$ following the methods for RACE as described above.

\subsection{Phylogeny construction}

The deduced amino acid sequences for the blue crab hif- $\alpha$ and arnt/ hif- $\beta$ cDNAs were aligned to amino acid sequences obtained from GenBank (http://www.ncbi.nlm.nih.gov/) for hif- $\alpha$ and arnt/hif- $\beta$ transcripts and genes from vertebrates and other invertebrates. Sequences were aligned using ClustalX software (Larkin et al., 2007), and a phylogeny was constructed in MEGA v.5 (Tamura et al., 2011), using the Neighbor-Joining method and a p-distance model for tree construction (Saitou and Nei, 1987). All positions containing alignment gaps were eliminated only in pairwise sequence comparisons (pairwise deletion of gaps). Confidence values for clusters of associated taxa were subsequently obtained by bootstrap tests (1000 replicates).

\subsection{SYBR green real-time quantitative RT-PCR assays}

Total RNA was extracted from gill, hepatopancreas, gonads, anaerobic light muscle and aerobic dark muscle tissues of male and female blue crabs using TRI-Reagent (Molecular Research Center) with bromochloropropane. The resulting RNA was DNase I treated (Turbo DNA-free, Ambion) and quantified by spectrophotometry (Nanodrop 2000, ThermoScientific). The DNase I treated total RNA was then reverse transcribed in $10 \mu \mathrm{L}$ reactions by incubating $0.5 \mu \mathrm{g}$ of total RNA template $(4 \mu \mathrm{L})$ with $2.0 \mu \mathrm{L}$ of GoScript ${ }^{\mathrm{TM}} 5 \times$ reaction buffer, $1.0 \mu \mathrm{L}$ of $\mathrm{MgCl}_{2}(25 \mathrm{mM}), 0.25 \mu \mathrm{L}$ of RNaseOUT ( $40 \mathrm{U} / \mu \mathrm{L}$ ) (Invitrogen), $0.5 \mu \mathrm{L}$ of random hexamer $(500 \mathrm{ng} / \mathrm{mL}$ ) (Promega), $0.5 \mu \mathrm{L}$ dNTPs (stock of $10 \mathrm{mM}$ each of dCTP, dGTP, dTTP and dATP; Promega), and $0.25 \mu \mathrm{L}$ of GoScript Reverse Transcriptase (Promega), under a thermal profile of $25^{\circ} \mathrm{C}$ for $5 \mathrm{~min}$ followed by $42{ }^{\circ} \mathrm{C}$ for $60 \mathrm{~min}$ and $70{ }^{\circ} \mathrm{C}$ for 15 min (MyCycler thermal cycler, Bio-Rad).

Primers for SYBR green quantitative real-time PCR assays were designed (Primer Express 2.0, Applied Biosystems, Inc.) to protein coding regions of the partial cDNAs for hif- $\alpha$ and arnt/hif- $\beta$ from blue crab. Primers were also designed for $\beta$-actin from blue crab (GenBank accession no. DQ084066) for use as a control gene. All primers were synthesized by Integrated DNA Technologies (Coralville, IA, USA) (Table 1). Specificity of these SYBR green primer sets was confirmed by sequencing, as well as by melt-curve analysis during all quantitative PCR runs.

Quantitative real-time PCR was conducted in $16 \mu \mathrm{L}$ reactions. Each reaction contained $4.22 \mu \mathrm{L}$ nuclease-free water (Sigma-Aldrich, St. Louis, MO, USA), $8.0 \mu \mathrm{L}$ GoTaq ${ }^{\circledR}$ qPCR Master Mix (Promega), $0.64 \mu \mathrm{L}$ each of forward and reverse primers $(5 \mu \mathrm{M})$, and $2.5 \mu \mathrm{L}$ of reverse-transcribed cDNA template. The PCR thermal profile for each reaction was $50{ }^{\circ} \mathrm{C}$ for $2 \mathrm{~min}, 95^{\circ} \mathrm{C}$ for $10 \mathrm{~min}, 42$ cycles of $95^{\circ} \mathrm{C}$ for $15 \mathrm{~s}$ and $59{ }^{\circ} \mathrm{C}$ for $1 \mathrm{~min}$, and all assays were run on a Bio-Rad iCycler with a MyiQ ${ }^{\mathrm{TM}}$ Single Color PCR Detection System (Bio-Rad). Melt curve analysis was also performed to confirm amplification of a single product and the absence of primerdimers. For each gene, a standard curve was made from a pool of RNA from muscle that included samples representing all treatments and sexes. Each standard was serially diluted and assayed in triplicate. DNA

Table 1

Gene-specific primers for SYBR green quantitative real-time RT-PCR assays.

\begin{tabular}{|c|c|c|c|c|}
\hline Transcript & Primer & Nucleotide sequence ( $5^{\prime}$ to $3^{\prime}$ ) & $\begin{array}{l}\text { Amplicon size } \\
\text { (bp) }\end{array}$ & $\begin{array}{l}\text { Efficiency } \\
\text { (avg.) }\end{array}$ \\
\hline \multirow[t]{2}{*}{ hif- $\alpha$} & Sense & GCAGACACTCGCTCGACATG & 171 & $99.5 \%$ \\
\hline & Antisense & CAACCTGGCCCTTGTTCAAC & & \\
\hline \multirow[t]{2}{*}{ arnt/hif- $\beta$} & Sense & CGACGGCTTCCTCTTTGTGG & 160 & $101.1 \%$ \\
\hline & Antisense & TGAGCTGCTCCCGAACCTT & & \\
\hline \multirow[t]{2}{*}{$\beta$-actin } & Sense & ATGACCACTGCCGCTTCTTC & 191 & $99.2 \%$ \\
\hline & Antisense & GGATGTCCACGTCACACTTCA & & \\
\hline
\end{tabular}


contamination was assessed for each gene by analyzing RNA samples that were not reverse-transcribed, and each qPCR run included wells without cDNA template to further control for contamination. For each gene, correlation coefficients $\left(\mathrm{r}^{2}\right)$ for the standard curve ranged from 0.976 to 0.999 . PCR efficiencies for each gene were calculated using the equation: efficiency $=\left[10^{(-1 / \text { slope })}-1\right]$, and are provided in Table 1.

Transcript abundance for $\beta$-actin was quantified as the normalizing gene. Within each tissue examined, transcript levels of $\beta$-actin were stable across treatments (range: $p=0.249-0.988$ ); use of $\beta$ actin has also been validated previously in crustaceans as a normalizing gene for experiments in which oxygen and carbon dioxide levels are varied (Rathburn et al., in review). For each gene, relative mRNA levels were subsequently calculated using the standard curve and normalized to $\beta$-actin mRNA expression. Finally, transcript abundance for each gene of interest was expressed as a relative level by dividing the resulting values by the mean values of males in the control treatment group.

\subsection{Statistical analysis}

All statistical analyses were performed with the statistical software package JMP (v. 7). Where required, data were $\log _{10}$ or square roottransformed to meet the assumptions of normality and homogeneity of variance, as confirmed by the Shapiro-Wilk and Bartlett's tests, respectively. A one-way ANOVA model was used to test for an effect of treatment $(\mathrm{N}, \mathrm{H}$, or $\mathrm{HH})$ in the gill, hepatopancreas and gonad tissues. In the muscle tissue, a two-way ANOVA model was used with treatment, muscle fiber-type, and treatment $*$ fiber-type interaction as factors. Post-hoc comparisons were made with Tukey's Honestly Significant Difference test (HSD). Where variance could not be made equal through transformation a one-way Welch ANOVA was performed on untransformed data. Values are reported as means \pm SEM, and statistical differences were accepted at $\mathrm{p}<0.05$ and considered moderately significant at $\mathrm{p}<0.10$. Inter-tissue and inter-sex statistical comparisons of hif- $\alpha$ and arnt/hif- $\beta$ mRNA levels were not conducted due to methodological constraints that prevented the authors from simultaneously measuring relative mRNA levels from all tissues and both sexes at once.

\section{Results}

3.1. Isolation and sequencing of cDNAs encoding hif- $\alpha$ and arnt/hif- $\beta$ from blue crab

RT-PCR using degenerate primers designed to arnt/hif- $\beta$ from other species identified a partial length cDNA in the blue crab. BLAST analysis of this fragment confirmed its similarity to arnt/hif$\beta$. Subsequent extension of this initial partial cDNA using $5^{\prime}-$ and 3'-rapid extension of cDNA ends (RACE) generated a $791 \mathrm{bp}$ partial cDNA encoding a deduced sequence of 263 amino acids of putative arnt/hif- $\beta$ from blue crab (GenBank accession no. JN673811). Likewise, gene-specific primers designed to an existing partial cDNA sequence of $1491 \mathrm{bp}$ nucleotides for hif- $\alpha$ from blue crab (EF568606) were used in 5'- and 3'-RACE PCR reactions to obtain an extended partial cDNA sequence of $3226 \mathrm{bp}$ nucleotides encoding an partial opening reading frame of $3079 \mathrm{bp}$ nucleotides with a deduced amino acid sequence of 1026 residues, and $147 \mathrm{bp}$ nucleotides of the $3^{\prime}$ untranslated region (UTR) (JN673810).

BLAST (http://blast.ncbi.nim.nih.gov/Blast.cgi) and phylogenetic analyses of the deduced amino acid sequence of these cDNAs from blue crab confirmed their identities as hif- $\alpha$ and arnt/hif- $\beta$. Phylogenetic analyses of the deduced amino acid sequence of the hif- $\alpha$ cDNA from blue crab illustrated its similarity to all currently identified hif- $\alpha$-type cDNAs in Crustacea, and revealed that these hif genes of crustaceans are not part of the hif- $1 \alpha$ clade of vertebrates, but rather are part of what appears to be a single invertebrate hif- $\alpha$ gene that is ancestral to the divergence of the genes encoding hif- $1 \alpha$, hif- $2 \alpha$, and hif- $3 / 4 \alpha$ in mammals and teleost fishes (Fig. 1). Given that the deduced amino acid sequence of the blue crab cDNA identified here is not monophyletic with vertebrate HIF- $1 \alpha$ proteins, we refer to it simply as hif- $\alpha$, and not hif- $1 \alpha$ as it has been previously called for other crustaceans.

Similarly, phylogenetic analysis of the deduced amino acid sequenced for the partial cDNA encoding putative HIF- $\beta$ from blue crab confirmed the identity of this cDNA as part of the arnt/hif- $\beta$ family of genes (Fig. 2). Similar to the relationships observed with HIF- $\alpha$, the blue crab HIF- $\beta$ protein showed closest similarity to HIF- $\beta$ identified previously in the Pacific whiteleg shrimp, L. vannamei, and clustered as a member of the larger clade of invertebrate arnt/hif- $\beta$ genes, which was monophyletic from the arnt/hif- $\beta$ genes of vertebrates.

\subsection{Expression of HIF- $\alpha$ and ARNT/HIF- $\beta$ gene transcripts}

\subsubsection{Transcript levels are muscle fiber type-dependent}

A two-way ANOVA model revealed a significant treatment by fibertype interaction effect on hif- $\alpha$ transcript abundance in both the female $\left(\mathrm{F}_{2,61}=8.167, \mathrm{p}=0.007\right)$ and male $\left(\mathrm{F}_{2,59}=6.0946, \mathrm{p}=0.0039\right)$ crabs. Such a result indicates that the effect of treatment on mRNA transcript abundance is significantly different between the light and dark muscle fibers. In the female crabs, pairwise statistical post-hoc comparisons revealed that relative hif- $\alpha$ mRNA levels in the light fibers were significantly lower in both $\mathrm{H}$ and $\mathrm{HH}$ than in the normoxic control group, while in the dark fibers there was a significant increase in $\mathrm{HH}$ of hif- $\alpha$ mRNA levels above N. The same trend was observed in the male crabs; hif- $\alpha$ mRNA levels in the light fibers were significantly lower in both $\mathrm{H}$ and $\mathrm{HH}$ than $\mathrm{N}$, while in the dark fibers there was a detectible, although insignificant, increase in hif- $\alpha$ mRNA levels under $\mathrm{H}$ or $\mathrm{HH}$ (Fig. 3). Furthermore, in both sexes hif- $\alpha$ transcript abundance is significantly higher in the light fibers than the dark fibers under normoxia (Fig. 3). A two-way ANOVA also revealed a significant tissue effect on arnt/hif- $\beta$ transcript abundance in both the female $\left(F_{1,61}=6.94, p=0.0107\right)$ and male $\left(F_{1,59}=20.3848, p<0.0001\right)$ crabs, with relative mRNA levels being significantly higher in the light muscle fibers than the dark muscle fibers. However, no significant effect of treatment was detected on arnt/ hif- $\beta$ levels in either sex (female, $\mathrm{p}=0.3212$; male, $\mathrm{p}=0.6487$ ).

\subsubsection{Relative transcript abundance responses are tissue-specific}

One-way ANOVA models revealed a significant effect of treatment on hif- $\alpha$ transcript abundance in the gill tissue (Fig. 4) (males: $\mathrm{F}_{2,30}=4.8119, \mathrm{p}=0.0154$; females: $\mathrm{F}_{2,28}=3.8106, \mathrm{p}=0.0344$ ), but no effect of treatment was detected in either the gonads (testis, $\mathrm{p}=$ 0.3891 ; ovary, $\mathrm{p}=0.7120$ ) or the hepatopancreas (male, $\mathrm{p}=0.8360$; female, $\mathrm{p}=0.0841$ ). In the gill tissue, relative hif- $\alpha$ mRNA levels were significantly lower in the males exposed to $\mathrm{H}(\mathrm{p}<0.05)$, compared to $\mathrm{HH}$ and $\mathrm{N}$, and in the females exposed to $\mathrm{HH}(\mathrm{p}<0.05)$ and $\mathrm{H}(\mathrm{p}<0.10)$, compared to $\mathrm{N}$. One-way ANOVA models determined that there was no significant effect of treatment on arnt/hif- $\beta$ mRNA transcripts levels in any tissue type (Fig. 5).

\section{Discussion}

Vertebrates are known to have evolved multiple hif- $\alpha$ genes. Three distinct hif- $\alpha$ paralogs, hif- $1 \alpha$, hif- $2 \alpha$, and hif- $3 \alpha$, have been identified in mammals, while teleost fish are reported to have a separate ortholog to mammalian hif-3 $\alpha$ - referred to as hif- $4 \alpha$ - in addition to hif- $1 \alpha$ and hif-2 $\alpha$ (Law et al., 2006; Rytkönen et al., 2011). This pattern of gene divergence amongst vertebrates is clearly demonstrated in our current hif- $\alpha$ phylogeny (Fig. 1). In contrast, all invertebrate taxa (including crustaceans) examined to date seem to have evolved only one hif- $\alpha$ gene. Our phylogenetic analysis, as well as evolutionary analyses described elsewhere (Li and Brouwer, 2007; Soñanez-Organis et al., 2009; Piontkivska et al., 2011), indicate that the crustacean hif- $\alpha$ gene is not monophyletic with the vertebrate hif- $1 \alpha$ gene, but rather is the evolutionary precursor to all vertebrate forms of hif- $\alpha$, which have 


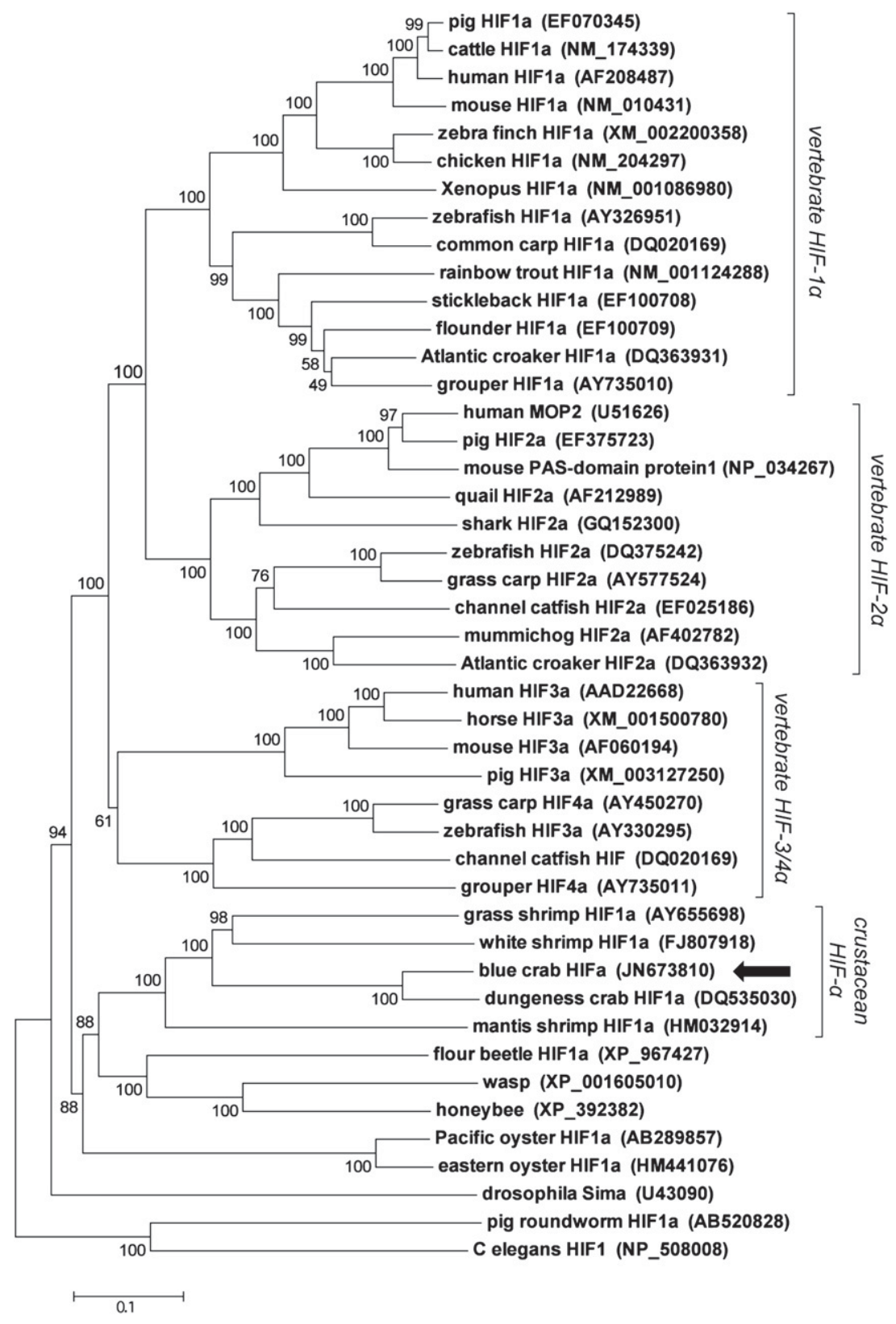

Fig. 1. Phylogenetic tree of deduced amino acid sequences for HIF- $\alpha$ cDNAs and genes from vertebrates and other invertebrates. The partial cDNA identified here from blue crab (C. sapidus) (GenBank accession no. JN673810) is shown next to the arrow. Clades for vertebrate HIF-1 $\alpha, \mathrm{HIF}-2 \alpha$ and HIF-3/4 $\alpha$ are demarked by brackets and comprise part of a larger clade of vertebrate HIF- $\alpha$ proteins. The clade of crustacean HIF- $\alpha$, which includes the new cDNA identified here in blue crab (arrow), is also denoted. The tree was assembled with the Neighbor-Joining method with pairwise deletion of gaps, and bootstrap values from 1000 replicates are indicated at each node. GenBank accession numbers for all each sequence are provided in parentheses following the taxon designation.

undergone subsequent gene duplication events to create the vertebrate hif- $1 \alpha$, hif- $2 \alpha$, and hif-3 $\alpha /$ hif- $4 \alpha$ subclades (Fig. 1 ). For that reason, we use the nomenclature hif- $\alpha$ - rather than hif- $1 \alpha$ - for the blue crab cDNA identified herein, and advocate that the nomenclature of all crustacean hif- $\alpha$ cDNAs or genes should be referred to similarly (see also Piontkivska et al., 2011).

In mammalian and fish systems, hif- $1 \alpha$ is believed to be the principal regulator of cellular oxygen homeostasis (Wenger, 2002), facilitating changes in the expression of hypoxia-inducible target genes primarily via post-translational modifications of the HIF- $\alpha$ and ARNT/HIF- $\beta$ subunits, rather than through transcriptional-level changes (Pisani and Dechesne, 2005). The role and regulation of hif- $2 \alpha$, hif- $3 \alpha$, and hif- $4 \alpha$, however, are less well understood. Regulation of hif- $2 \alpha$ expression is also thought to occur primarily at the translational level, whereas hif$3 \alpha$ and hif- $4 \alpha$ demonstrate regulation primarily at the transcriptional level (Heidbreder et al., 2003; Law et al., 2006). Fewer studies still have examined the regulation of crustacean hif- $\alpha$ during low oxygen conditions (Li and Brouwer, 2007; Soñanez-Organis et al., 2009), although available findings suggest that transcriptional regulation does occur (Soñanez-Organis et al., 2009). Presently, we hoped to clarify whether crustacean hif- $\alpha$ (from C. sapidus) showed a transcriptional response to hypoxia, as well as the more ecologically relevant condition of hypercapnic hypoxia.

Our findings confirm that the crustacean hif- $\alpha$ and arnt/hif- $\beta$ homologs are constitutively expressed in all of the $C$. sapidus tissues we examined, and that acute exposure to hypoxia and hypercapnic hypoxia leads to significant changes in relative transcript abundance for hif- $\alpha$ (Figs. 3 and 4), but not arnt/hif- $\beta$ (Figs. 3 and 5). Furthermore, we observed that the changes in hif- $\alpha$ mRNA levels in response to short-term $(1 \mathrm{~h}) \mathrm{H}$ and $\mathrm{HH}$ exposures were tissue-specific, occurring in the gill and muscle 


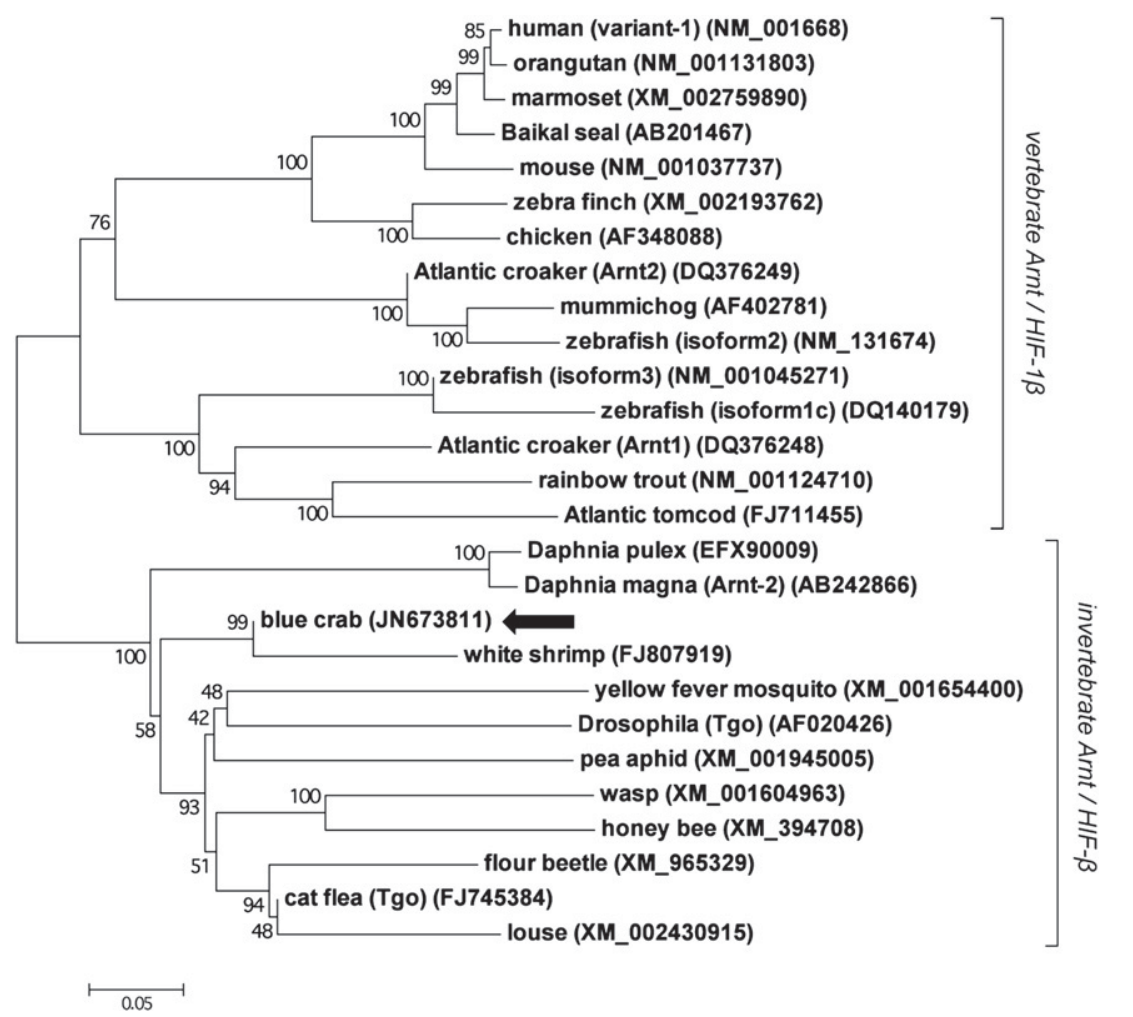

Fig. 2. Phylogenetic tree of ARNT/HIF- $\beta$ deduced amino acid sequences from vertebrates and other invertebrates. The full-length cDNA identified here from blue crab ( $C$. sapidus) (GenBank accession no. JN673811) is shown next to the arrow. The clade for vertebrate ARNT/HIF- $\beta$ is demarked by brackets. The clade of invertebrate ARNT/HIF- $\beta$, which includes the new cDNA identified here in blue crab (arrow), is also denoted. The tree was assembled using the Neighbor-Joining method with pairwise deletion of gaps, and bootstrap values from 1000 replicates are indicated at each node. GenBank accession nos. for each sequence are provided in parentheses following the taxon designation.

tissues, but not the hepatopancreas or gonadal tissues. This phenomenon of tissue-dependent transcriptional regulation of hif- $\alpha$ during hypoxia exposure has been observed before in other invertebrates. In fact, hif- $\alpha$ mRNA levels in the whiteleg shrimp (L.vannamei) were sensitive to short-term hypoxia $(\leq 24 \mathrm{~h})$ in the gill and muscle tissue, but not in the hepatopancreas (Soñanez-Organis et al., 2009), exactly as we observed. In the Eastern oyster (Crassostrea virginica), long-term hypoxia ( 2 weeks) had a significant effect on hif- $\alpha$ mRNA levels in the gill tissue,
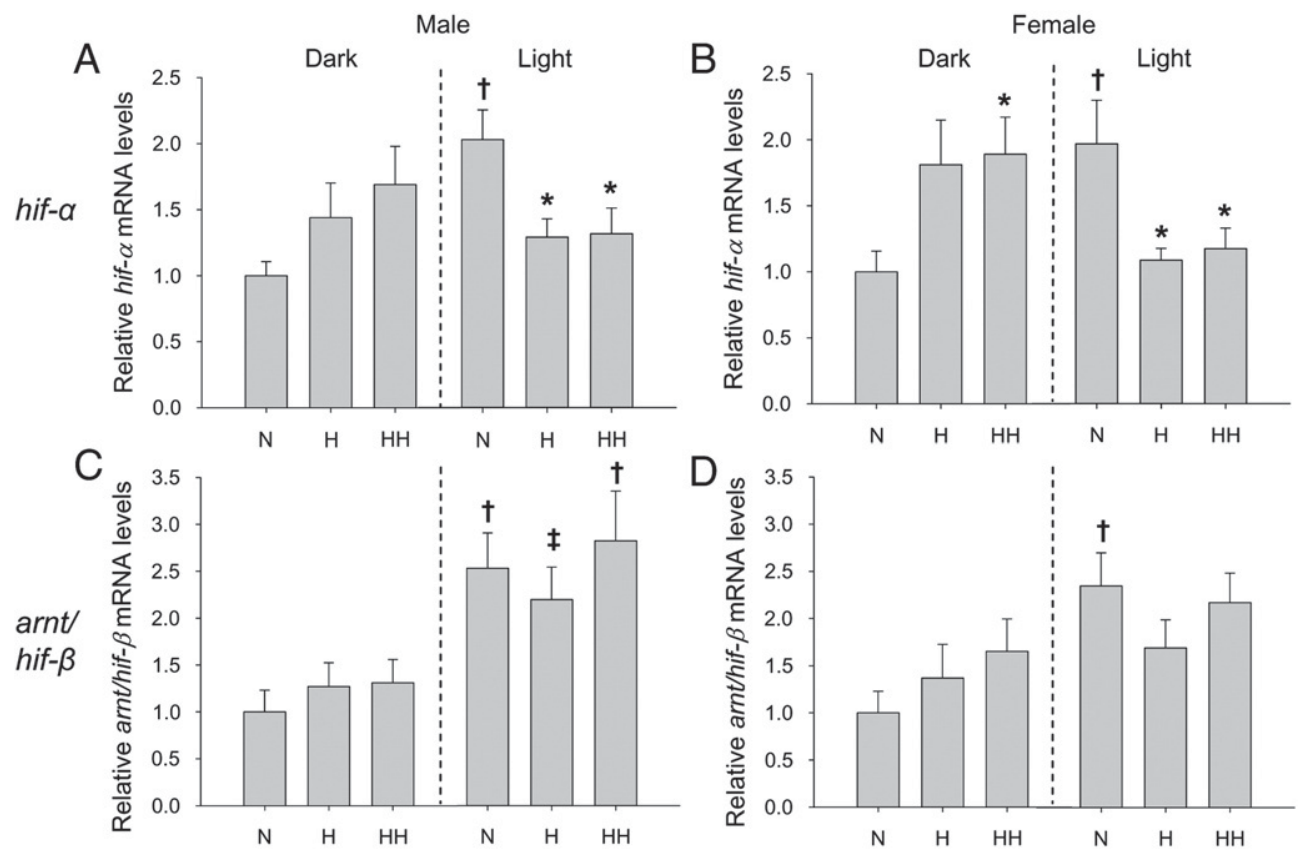

Fig. 3. Variation in hif- $\alpha(A, B)$ and arnt/hif- $B$ (C, D) relative mRNA levels under short-term ( $1 \mathrm{~h})$ conditions of $\mathrm{N}$, $\mathrm{H}$ or $\mathrm{HH}$ in oxidative dark and glycolytic light muscle in male (right panel) and female (left panel) C. sapidus. Two-way ANOVA was used to compare experimental treatments across fiber-types. * denotes a significant difference from the normoxic control group in that muscle fiber type $(p<0.05)$. $\dagger$ denotes a significant difference between the dark and light fiber types for that treatment $(p<0.05)$. $\ddagger$ denotes a moderately significant difference between the dark and light fiber types for that treatment $(\mathrm{p}<0.1)$. Error bars represent mean \pm SEM. For each treatment group $n=8-14$. 


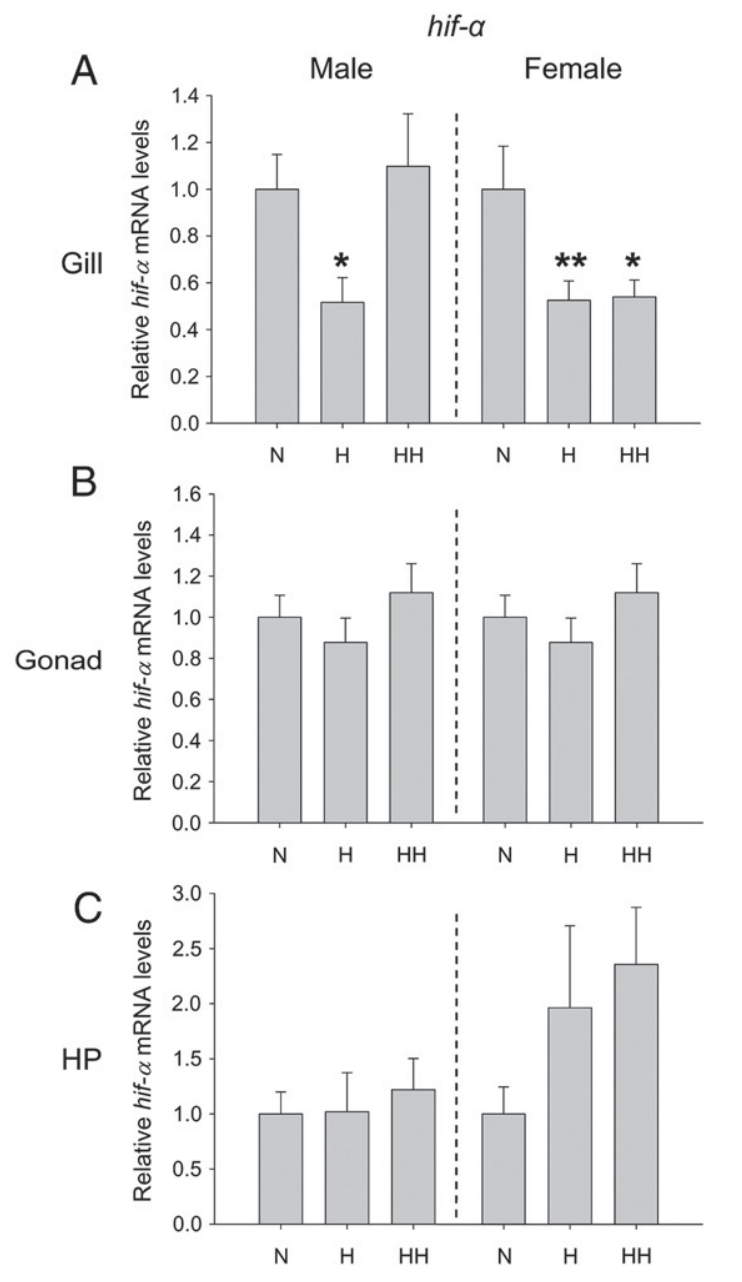

Fig. 4. Effect of gas treatment ( $\mathrm{N}, \mathrm{H}$ or $\mathrm{HH})$ on relative hif- $\alpha$ mRNA levels in gill (A), gonad (B), and hepatopancreas (C) tissue in male (right) and female (left) C. sapidus. One-way ANOVA was used to compare experimental treatments within each tissue. * denotes a significant difference from the normoxic control group in that muscle fiber type $(\mathrm{p}<0.05) .{ }^{* *}$ denotes a moderately significant difference from the normoxic control group in that muscle fiber type $(\mathrm{p}<0.10)$. Error bars represent mean $\pm S E M$. For each treatment group $n=8-11$

but not the hepatopancreas or muscle tissue (Piontkivska et al., 2011). Tissue-specific changes in HIF- $\alpha$ protein level have also been widely observed during low oxygen exposure in vertebrates (Stroka et al., 2001; Rissanen et al., 2006).

We have clearly demonstrated that there is a transcriptional level response to hypoxia by hif- $\alpha$ in $C$. sapidus, yet this does not preclude there being translational regulation as well. A lack of well-established antibodies to the crustacean HIF- $\alpha$ protein presently prohibits quantification of the protein level response to $\mathrm{H}$ and $\mathrm{HH}$ in the blue crab. However, other studies have shown that hypoxia can lead to an increase in invertebrate HIF- $\alpha$ protein levels [i.e., Antarctic limpet (Weihe, 2009), gall fly (Morin et al., 2005) and Drosophila (see Gorr et al., 2006)], suggesting that regulation of HIF- $\alpha$ protein does also exist. In all, though, our results suggest a model of hypoxia-induced regulation of hif- $\alpha$ transcript abundance in crustaceans that is different from that of typical hif- $1 \alpha$ transcriptional regulation in mammalian systems. This point is emphasized by the fact that we observed a significant decrease in hif- $\alpha$ gene transcript expression in response to low oxygen in the gill and oxidative muscle tissue [as did Soñanez-Organis et al. (2009)], which stands in contrast to the majority of previously observed vertebrate hypoxic responses, where hif- $1 \alpha$ transcript levels typically increase or remain unchanged during hypoxic exposure (depending on the taxon and the tissue) while
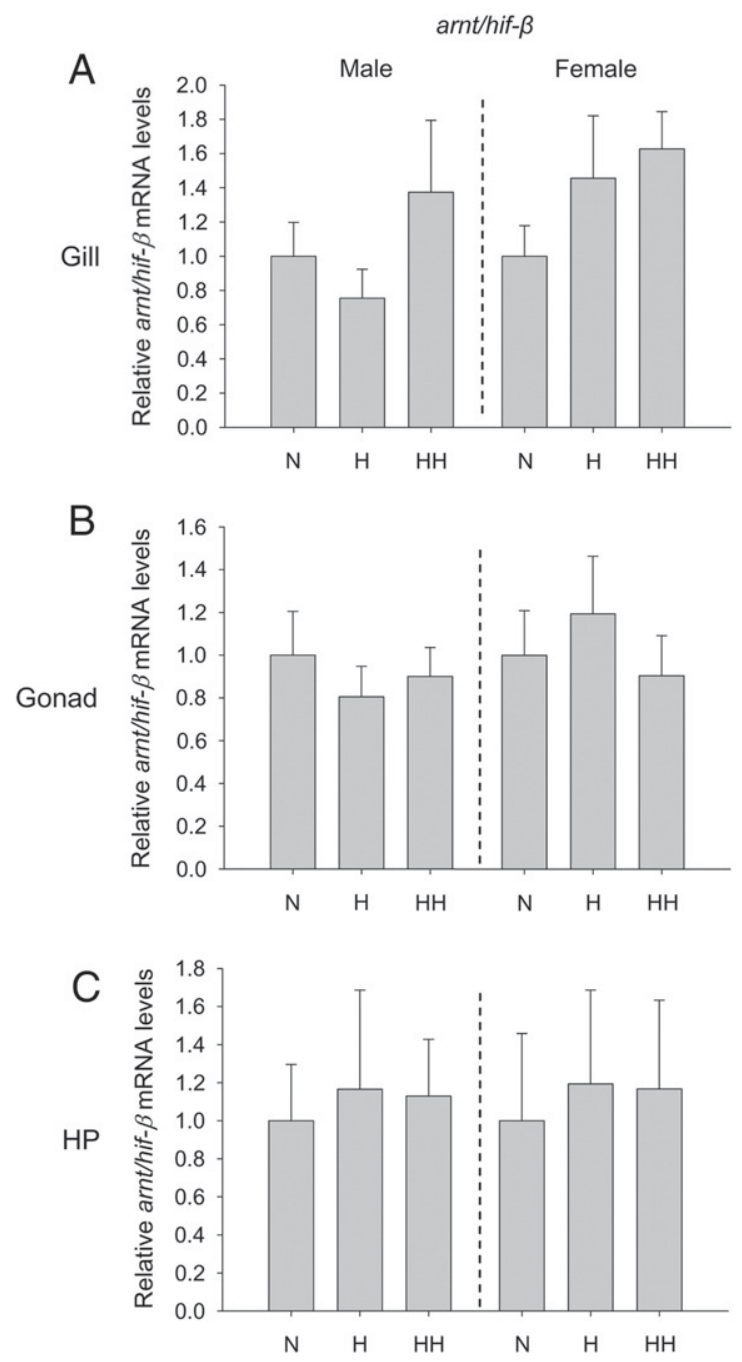

Fig. 5. Effect of gas treatment $(\mathrm{N}, \mathrm{H}$ or $\mathrm{HH})$ on relative arnt/hif- $\mathrm{B}$ mRNA levels in gill (A), gonad (B), and hepatopancreas (C) tissue in male (right) and female (left) C. sapidus. One-way ANOVA was used to compare experimental treatments within each tissue. There were no significant differences in relative expression between the control and treatment groups in any tissue. Error bars represent mean \pm SEM. For each treatment group $n=7-14$.

translational modification results in increasing levels of the HIF- $1 \alpha$ protein subunit (Stroka et al., 2001).

The marked differences in the regulation of the HIF-mediated hypoxic response between crustaceans and vertebrates may be a reflection of the disparate adaptive responses to low environmental $\mathrm{Po}_{2}$ between the more 'hypoxia-tolerant' invertebrates and 'hypoxia-sensitive' vertebrates. Endothermic vertebrates are largely intolerant of declining ambient $\mathrm{PO}_{2}$ and tend to be sensitive to even the slightest periods of oxygen deprivation (e.g., Duffy et al., 1972). During bouts of low oxygen exposure in mammals, HIF transcription factors mediate a hypoxic response that is largely aimed at ATP 'compensation'; that is, attempting to support a similar level of energy demand by switching from aerobic to anaerobic means of ATP production (Boutilier and St-Pierre, 2000; Seagroves et al., 2001; Gorr et al., 2006). Conversely, hypoxia tolerance in invertebrates - notably within the crustaceans and insects - is widespread and mediated by a strikingly different adaptive response. Invertebrate survival during hypoxia is made possible not by compensation, but primarily by ATP conservation (Larade and Storey, 2002; Gorr et al., 2006). This ATP conservation is accomplished by entering a reversible hypometabolic state. During this metabolic depression the most energetically expensive cellular functions (i.e., protein synthesis, protein degradation and ion-motive ATPases) are drastically suppressed, 
thereby reducing overall ATP consumption to match the concomitant decline in ATP supply and achieving a new, balanced steady-state (Boutilier and St-Pierre, 2000; Hochachka and Somero, 2002; Gorr et al., 2006). At this time, we do not understand the role, if any, of HIF in regulating the metabolic depression strategy of 'hypoxia-tolerant' invertebrates. Although there is recent (unpublished) evidence that the Drosophila gene thor, which is induced during the hypoxic response and is only expressed in the presence of HIF, may play a role in inhibiting protein synthesis thereby implicating a possible regulatory role for HIF in metabolic depression (Gorr et al., 2010).

The hypoxic HIF response in crustaceans/invertebrates may be particularly important in the gills, as levels of hif- $\alpha$ mRNA are often highest in this tissue under both normoxic and hypoxic conditions (SoñanezOrganis et al., 2009; Piontkivska et al., 2011). Furthermore, our results indicate that the effects of hypoxia and hypercapnic hypoxia on hif- $\alpha$ gene transcription were most dramatic in the gill tissue, an observation mirrored during hypoxic exposure in the whiteleg shrimp (SoñanezOrganis et al., 2009) and the Eastern oyster (Piontkivska et al., 2011). It is also notable that in our present study with blue crab - and in previous studies of other invertebrates (Li and Brouwer, 2007; SoñanezOrganis et al., 2009; Ivanina et al., 2010; Piontkivska et al., 2011; Susarellu et al., 2012) - that hif- $\alpha$ mRNA levels in the hepatopancreas consistently show no response to hypoxia or anoxia, and under normoxic conditions both the transcript and protein are often found at relatively lower levels (Stroka et al., 2001; Kodama and Rahman, 2011). But, why might hif- $\alpha$ transcriptional regulation in the gills be so distinct from other tissues? The gills have a well-established role in respiration, osmoregulation, acid-base balance, immune function and detoxification, and are the most obvious candidate tissues to first detect a drop in environmental $\mathrm{Po}_{2}$. The hepatopancreas, on the other hand, is also a highly metabolic, multifunctional tissue involved in excretion, molting, lipid/carbohydrate metabolism, synthesis and secretion of digestive enzymes, and synthesis of hemocyanin. The metabolic oxygen demands of the gill and hepatopancreas tissues in estuarine crabs are quite similar, and relatively high (Houlihan et al., 1990; Maciel et al., 2004). Thus, eliciting a HIF-mediated metabolic suppression under low-oxygen seems appropriate (and perhaps critical) for both of these tissues. Nevertheless, there does not appear to be a transcription-level response of hif- $\alpha$ to hypoxia in the hepatopancreas as in the gill, suggesting that tissue-specific regulation of HIF may involve transcriptional regulation in some tissues but translational regulation in others, or that the hypoxia-driven decrease in hif- $\alpha$ mRNA levels in the gill and oxidative muscle (relative to the unchanging levels in the hepatopancreas) is actually meant to dampen the hypoxic response in tissues where HIF- $\alpha$ protein levels are already constitutively high.

Another interesting finding was that the effect of hypercapnic hypoxia on hif- $\alpha$ gene expression in the gill tissue was different between sexes. While females showed a dramatic reduction in hif- $\alpha$ mRNA levels during both $\mathrm{H}$ and the more severe $\mathrm{HH}$, males had a significant decline only during hypoxia. In the oxidative muscle tissue, however, both sexes exhibit the same significant decline in hif- $\alpha$ transcript abundance during $\mathrm{H}$ and $\mathrm{HH}$. Female blue crabs, unlike male blue crabs, experience a 'terminal molt' as adults after which time they presumably do not molt again. In crustaceans, invading bacteria and pathogens are inactivated by the immune system and temporarily accumulated in the gill tissue, where they are stored until the next molt cycle (White et al., 1985; Martin et al., 2000). During ecdysis, the old epicuticle of the gill tissue (including any stored pathogens) is shed, thereby 'cleaning' the gill tissue of any occluding waste material. It is possible that an adult female blue crab will be more sensitive to the physiological challenges associated with high oxygen and low $\mathrm{pH}$ - challenges that must be met in large part by the gill tissue - if they do not continue to experience the restorative benefits of additional molt cycles during adulthood.

In addition to investigating the general tissue-specific effects of hypoxia and hypercapnic hypoxia on hif- $\alpha$ expression, we also compared hif- $\alpha$ and arnt/hif- $\beta$ expression between skeletal muscles predominantly composed of either oxidative 'dark' fibers or glycolytic 'light' fibers. Energy for contraction comes from either aerobic oxidative phosphorylation or anaerobic glycolysis in the dark and light fibers, respectively. The different metabolic strategies serve to most effectively meet the specific mechanical and functional demands of each discrete fiber type - the endurance contractions of the dark fiber, or the rapid, high-force contractions of the light fibers. Given the role of hif- $\alpha$ as the primary molecular oxygen-sensor, we expected to see differences in its transcript abundance between these two metabolically distinct fiber types. We have shown herein that (a) under normoxic conditions both hif- $\alpha$ and arnt/hif- $\beta$ mRNAs are constitutively expressed at higher relative levels in the glycolytic light fibers than the oxidative dark fibers, (b) there is a significant decrease in hif- $\alpha$ transcript abundance after acute exposure to both hypoxia and hypercapnic hypoxia in the glycolytic light fibers only, but (c) there is a moderate increase in hif- $\alpha$ mRNA relative levels after exposure to hypercapnic hypoxia in the oxidative dark fibers, and (d) that arnt/hif- $\beta$ transcriptional dynamics are expectedly insensitive to both $\mathrm{H}$ and $\mathrm{HH}$.

Pisani and Dechesne (2005) observed an identical muscle fibertype dependence on hif- $\alpha$ gene expression in normoxic rats, whereby hif- $\alpha$ mRNA (and protein) levels were constitutively higher in three predominantly glycolytic muscles compared to the predominantly oxidative soleus muscle. They ultimately inferred that the $\mathrm{O}_{2}$ regulation system was different between these two fiber types. The HIF-1 complex was implicated as the primary $\mathrm{O}_{2}$ regulation system in glycolytic fibers, but myoglobin - which is found in much higher concentrations in oxidative fibers than the glycolytic fibers - is believed to serve an analogous role in oxidative fibers. C. sapidus, however, does not contain myoglobin in its skeletal muscle fibers and so the increased oxidative demands of the light fibers could not be met in this manner. Furthermore, although normoxic levels of hif- $\alpha$ mRNA are higher in glyolytic fibers than oxidative fibers, hypoxic exposure causes relative levels of this transcript to decrease in abundance rather than increase, as they do in oxidative dark fibers. The slight increase in hif- $\alpha$ levels in the oxidative fibers under environmental hypoxia is more consistent with the mammalian response to hypoxia, even if the magnitude of change at the transcription level is small. Nonetheless, it is important to note that the bulk of hif- $\alpha$ regulation in the oxidative fibers could also be occurring at the protein level, although that avenue was not presently explored.

In conclusion, we identified partial-length cDNAs encoding the two HIF subunits - hif- $\alpha$ and arnt/hif- $\beta$ - from the blue crab C. sapidus and demonstrated that hif- $\alpha$ transcripts in this species are present in multiple tissues under normoxic conditions. This work also provides evidence that blue crabs exhibit both tissue-specific and muscle fiber type-specific changes in relative hif- $\alpha$ mRNA levels under both hypoxia and hypercapnic hypoxia conditions. Given that blue crabs occupy estuarine habitats for a large portion of their life cycle, these tissuespecific transcriptional responses may indicate evolved, tissuespecific mechanisms for coping with exposure to short-term environmental hypoxia. And yet, as estuaries and coastal ecosystems become increasingly hypoxic and hypercapnic due to anthropogenic impacts, the general health and metabolic status of coastal organisms may become jeopardized. At present, we cannot predict the full effects of these environmental changes on the health and behavior of estuarine species like the blue crab until we have a more complete picture of the general hypoxia-induced HIF responses in these 'hypoxia-tolerant' species, and how those responses compare to responses in species that have not evolved under intermittent hypoxic conditions.

Supplementary data to this article can be found online at http:// dx.doi.org/10.1016/j.cbpa.2012.05.195.

\section{Acknowledgments}

The authors would like to acknowledge Matthew Birk for substantial laboratory assistance, Dr. Karen Burnett for methodological support, 
Colden Battey for aquatic facility support, and Nat Johnson, Casey Darling and Kristin Stover for their assistance with animal capture and husbandry. This work was supported by NSF grant \# IOS-0725245 awarded to Karen Burnett and LEB, as well as by North Carolina SeaGrant \# R/ MG-1003 to SCL.

\section{References}

Bell, G.W., Eggleston, D.B., Wolcott, T.G., 2003. Behavioral responses of free-ranging blue crabs to episodic hypoxia. II. Feeding. Mar. Ecol. Prog. Ser. 259, 227-235.

Boutilier, R., St-Pierre, J., 2000. Surviving hypoxia without really dying. Comp. Biochem. Physiol. A 126, 481-490.

Brown-Peterson, N.J., Manning, C.S., Patel, V., Denslow, N.D., Brouwer, M., 2008. Effects of cyclic hypoxia on gene expression and reproduction in a grass shrimp, Palaemonetes pugio. Biol. Bull. 214, 6-16.

Burgents, J.E., Burnett, K.G., Burnett, L.E., 2005. Effects of hypoxia and hypercapnic hypoxia on the localization and the elimination of Vibrio campbellii in Litopenaeus vannamei, the Pacific white shrimp. Biol. Bull. 208, 159-168.

Burnett, L.E., 1997. The challenges of living in hypoxic and hypercapnic aquatic environments. Am. Zool. 37, 633-640.

Burnett, L.E., Stickle, W.B., 2001. Physiological responses to hypoxia. In: Rabalais, N.N., Turner, R.E. (Eds.), Coastal Hypoxia: Consequences for Living Resources and Ecosystems, Coastal and Estuarine Studies. American Geophysical Union, Washington D.C., pp. 101-114.

Catron, T., Mendioloa, M.A., Smith, S.M., Born, J., Walker, M.K., 2001. Hypoxia regulates avian cardiac Arnt and HIF- $1 \alpha$ mRNA expression. Biochem. Biophys. Res. Commun. 282, 602-607.

Cheng, W., Liu, C., Hsu, J., Chen, J., 2002. Effect of hypoxia on the immune response of giant freshwater prawn Macrobrachium rosenbergii and its susceptibility to pathogen Enterococcus. Fish Shellfish Immunol. 23, 351-365.

Cheung, H.Y., 2008. Effects of hypoxia on sex determination and differentiation in the Japanese medaka (Oryzia latipes) (Master's dissertation). Retrieved from City U Theses and Dissertations. http://hdl.handle.net/2031/5517.

Cochran, R.E., Burnett, L.E., 1996. Respiratory responses of the salt marsh animals, Fundulus heteroclitus, Leiostomus xanthuras, and Palaemonetes pugio to the environmental hypoxia and hypercapnia and the organophosphate pesticide azinphosmethyl. J. Exp. Mar. Biol. Ecol. 1195, 125-144.

Coiro, L.L., Poucher, S.L., Miller, D.C., 2000. Hypoxic effects on growth of Palaemonetes vulgaris larvae and other species: using constant exposure data to estimate cyclic exposure response. J. Exp. Mar. Biol. Ecol. 247, 243-255.

Das, T., Stickle, W.B., 1993. Sensitivity of crabs Callinectes sapidus and C. similis and the gastropod Stramonita haemastoma to hypoxia and anoxia. Mar. Ecol. Prog. Ser. 98, 263-274.

de Beaucourt, A., Coumailleau, P., 2007. Molecular cloning and characterization of the Xenopus hypoxia-inducible factor 1alpha (xHIF1alpha). J. Cell. Biochem. 102 (6), 1542-1552.

de la Vega, E., Hall, M.R., Wilson, K.J., Reverter, A., Woods, R.G., Degnan, B.M., 2007. Stress-induced gene expression profiling in the black tiger shrimp Penaeus monodon. Physiol. Genomics 31, 126-138.

Diaz, R.J., 2001. Overview of hypoxia around the world. J. Environ. Qual. 30, 275-281.

Diaz, J.R., Rosenberg, R., 1995. Marine benthic hypoxia: a review its ecological effects and the behavioural responses of benthic marcofauna. Oceanogr. Mar. Biol. Annu. Rev. 33, 245-303.

Diaz, R.J., Rosenberg, R., 2008. Spreading dead zones and consequences for marine ecosystems. Science 321, 926-929.

Duffy, T.E., Nelson, S.R., Lowry, O.H., 1972. Cerebral carbohydrate metabolism during acute hypoxia and recovery. J. Neurochem. 19, 959-977.

Garlo, E.V., Milstein, C.B., Jahn, A.E., 1979. Impact of hypoxic conditions in the vicinity of Little Egg Inlet, New Jersey in summer 1976. Estuar. Coast. Mar. Sci. 8, 421-432.

Goldberg, E.D., 1995. Emerging problems in the coastal zone for twenty-first century. Mar. Pollut. Bull. 31, 152-158.

Gorr, T.A., Gassmann, M., Wappner, P., 2006. Sensing and responding to hypoxia via HIF in model invertebrates. J. Insect Physiol. 52, 349-364.

Gorr, T.A., Wichmann, D., Hu, J., Hermes-Lima, M., Welker, A.F., Terwilliger, N., Wren, J.F., Viney, M., Morris, S., Nilsson, G.E., Deten, A., Soliz, J., Gassmann, M., 2010. Hypoxia tolerance in animals: biology and application. Physiol. Biochem. Zool. 83, 733-742.

Heidbreder, M., Fröhlich, F., Jöhren, O., Dendorfer, A., Qadri, F., Dominiak, P., 2003. Hypoxia rapidly activates HIF-3 $\alpha$ mRNA expression. FASEB J. 17, 1541-1543.

Hochachka, P.W., Somero, G.N., 2002. Biochemical adaptation: mechanism and process in physiological evolution. Oxford University Press, New York.

Holman, J.D., Burnett, K.G., Burnett, L.E., 2004. Effects of hypercapnic hypoxia on the clearance of Vibrio campbellii in the Atlantic blue crab, Callinectes sapidus Rathbun. Biol. Bull. 206, 188-196.

Houlihan, D.F., Waring, C.P., Mathers, E., Gray, C., 1990. Protein synthesis and oxygen consumption of the shore crab Carcinus maenas after a meal. Physiol. Zool. 634, 735-756.

Ivanina, A.V., Sokolov, E.P., Sokolova, I.M., 2010. Effects of cadmium on anaerobic energy metabolism and mRNA expression during air exposure and recovery of an intertidal mollusk Crassostrea virginica. Aquat. Toxicol. 99, 330-342.

Kodama, K., Rahman, S., 2011. Assessment of hypoxia inducible factor-1a mRNA expression in mantis shrimp as a biomarker of environmental hypoxia exposure. Biol. Lett. http://dx.doi.org/10.1098/rsbl.2011.0887.

Larade, K., Storey, K.B., 2002. Reversible suppression of protein synthesis in concert with polysome disaggregation during anoxia exposure in Littorina littorea. Mol. Cell. Biochem. 232, 121-127.
Larkin, M.A., Blackshields, G., Brown, N.P., Chenna, R., McGettigan, P.A., McWilliam, H. Valentin, F., Wallace, I.M., Wilm, A., Lopez, R., Thompson, J.D., Gibson, T.J., Higgins, D.G., 2007. Clustal W and Clustal X version 2.0. Bioinformatics 23, 2947-2948.

Law, S.H.W., Wu, R.S.S., Ng, P.K.S., Yu, R.M.K., Kong, R.Y.C., 2006. Cloning and expression analysis of two distinct HIF-alpha isoforms - gcHIF-1alpha and gcHIF-4alpha from the hypoxia-tolerant grass carp, Ctenopharyngodon idellus. BMC Mol. Biol. 7, 15. http://dx.doi.org/10.1186/1471-2199-7-15.

Le Moullac, G., Soyez, C., Saulnier, D., Ansquer, D., Avarre, J.C., Levy, P., 1998. Effect of hypoxic stress on the immune response and the resistance to vibriosis of the shrimp Penaeus stylirostris. Fish Shellfish Immunol. 8, 621-629.

Lenihan, H.S., Peterson, C.H., 1998. How habitat degradation through fishery disturbance enhances impacts of hypoxia on oyster reefs. Ecol. Appl. 8, 128-140.

Li, T., Brouwer, M., 2007. Hypoxia-inducible factor, gsHIF, of the grass shrimp Palaemonetes pugio: molecular characterization and response to hypoxia. Comp. Biochem. Physiol. B 147, 11-19.

Maciel, F.E., Rosa, C.E., Santos, E.A., Monserrat, J.M., Nery, L.E.M., 2004. Daily variations in oxygen consumption, antioxidant defenses, and lipid peroxidation in the gills and hepatopancreas of an estuarine crab. Can. J. Zool. 82, 1871-1877.

Martin, G.G., Quintero, M., Quigley, M., Khosrovian, H., 2000. Elimination of sequestered material from the gills of decapod crustaceans. J. Crustac. Biol. 20, 209-217.

Maxwell, P.H., Wiesener, M.S., Chang, G.W., Clifford, S.C., Vaux, E.C., Cockman, M.E., Wykoff, C.C., Pugh, C.W., Maher, E.R., Ratcliffe, P.J., 1999. The tumour suppressor protein VHL targets hypoxia-inducible factors for oxygen-dependent proteolysis. Nature 399, 271-275.

McCrea-Strub, A., Kleisner, K., Sumaila, U.R., Swartz, W., Watson, R., Zeller, D., Pauly, D., 2011. Potential impact of the Deepwater Horizon oil spill on commercial fisheries in the Gulf of Mexico. Fisheries 36 (7), 332-336.

Melzner, F., Thomsen, J., Koeve, W., Oschlies, A., Gutowska, M.A., Bange, H.W., Hansen, H.P., Körtzinger, A., in press. Future ocean acidification will be amplified by hypoxia in coastal habitats. Mar. Biol. http://dx.doi.org/10.1007/s00227-012-1954-1.

Mikulski, C.M., Burnett, L.E., Burnett, K.G., 2000. The effects of hypercapnic hypoxia on the survival of shrimp challenged with Vibrio parahaemolyticus. J. Shellfish. Res. 19, 301-311.

Morin Jr., P., McMullen, D.C., Storey, K.B., 2005. Hif-1alpha involvement in low temperature and anoxia survival by a freeze tolerant Insect. Mol. Cell. Biochem. 280, 99-106.

Paschke, K., Cumillaf, J.P., Loyola, S., Gebauer, P., Urbina, M., Chimal, M.E., Pascual, C., Rosas, C., 2010. Effect of dissolved oxygen on respiratory metabolism, nutritional physiology, and immune condition of southern king crab Lithodes santolla (Molina, 1782) (Decapoda, Lithoidae). Mar. Biol. 157, 7-18.

Piontkivska, H., Chung, J.S., Ivanina, A.V., Sokolov, E.P., Techa, S., Sokolova, I.M., 2011. Molecular characterization and mRNA expression of two key enzymes of hypoxia-sensing pathways in eastern oysters Crassostrea virginica (Gmelin): hypoxia-inducible factor $\alpha$ (HIF- $\alpha$ ) and HIF-prolyl hydroxylase (PHD). Comp. Biochem. Physiol. D 6, 103-114.

Pisani, D.F., Dechesne, C.A., 2005. Skeletal muscle HIF-1 $\alpha$ expression is dependent on muscle fiber type. J. Gen. Physiol. 126, 173-178.

Rathburn, C.K., Sharp, N.J., Ryan, J.C., Beal, M., Cook, M., Chapman, R.W., Burnett, L.E., Burnett, K.G, in review. Transcriptomic responses of juvenile Pacific whiteleg shrimp, Litopenaeus vannamei, to hypoxia and hypercapnic hypoxia. J. Exp. Biol.

Rissanen, E., Tranberg, H.K., Sollid, J., Nilsson, G.E., Nikinmaa, M., 2006. Temperature regulates hypoxia-inducible factor-1 (HIF-1) in a poikilothermic vertebrate, crucian carp (Carassius carassius). J. Exp. Biol. 209, 994-1003.

Rytkönen, K.T., Williams, T.A., Renshaw, G.M., Primmer, C.R., Nikinmaa, M., 2011. Molecular evolution of the metazoan PHD-HIF oxygen-sensing system. Mol. Biol. Evol. 28, 1913-1926.

Saitou, N., Nei, M., 1987. The neighbor-joining method: a new method for reconstructing phylogenetic trees. Mol. Biol. Evol. 4, 406-425.

Salceda, S., Caro, J., 1997. Hypoxia-inducible factor 1alpha (HIF-1alpha) protein is rapidly degraded by the ubiquitin-proteasome system under normoxic conditions. Its stabilization by hypoxia depends on redox-induced changes. J. Biol. Chem. 272, 22642-22647.

Seagroves, T., Ryan, H., Lu, H., Wouters, B., Knapp, M., Thibault, P., Laderoute, K., Johnson, R., 2001. Transcription factor HIF-1 is a necessary mediator of the Pasteur effect in mammalian cells. Mol. Cell. Biol. 21, 3436-3444.

Seidman, E.R., Lawrence, A.L., 1985. Growth, feed digestibility, and proximate body composition of juvenile Penaeus vannamei and P. monodon grown at different dissolved oxygen levels. J. World Maricult Soc. 16, 333-346.

Semenza, G.L., 1999. Regulation of mammalian $\mathrm{O}_{2}$ homeostasis by hypoxia-inducible factor 1. Annu. Rev. Cell Dev. Biol. 15, 551-578.

Shang, E.H.H., Yu, R.M.K., Wu, R.S.S., 2006. Hypoxia affects sex differentiation and development, leading to a male-dominated population in zebrafish (Danio rerio). Environ. Sci. Technol. 40, 3118-3122.

Soitamo, A.J., Rabergh, C.M.I., Gassmann, M., Sistonen, L., Nikinmaa, M., 2001. Characterization of a hypoxia-inducible factor (HIF-1a) from rainbow trout. Accumulation of protein occurs at normal venous oxygen tension. J. Biol. Chem. 276, 19699-19705.

Soñanez-Organis, J.G., Peregrino-Uriarte, A.B., Gómez-Jiménez, S., López-Zavala, A., Forman, H.J., Yepiz-Plascencia, G., 2009. Molecular characterization of hypoxia inducible factor-1 (HIF-1) from the white shrimp Litopenaeus vannamei and tissue specific expression under hypoxia. Comp. Biochem. Physiol. C 150, 395-405.

Stewart, N.E., Shumway, D.L., Doudoroff, P., 1967. Influence of oxygen concentration on the growth of juvenile largemouth bass. J. Fish. Res. Bd. Canada 24, 475-494.

Stierhoff, K.L., Targett, T.E., Miller, K., 2006. Ecophysiological responses of juvenile summer and winter flounder to hypoxia: experimental and modeling analyses of effects on estuarine nursery quality. Mar. Ecol. Prog. Ser. 325, 255-266.

Stroka, D.M., Burkhardt, T., Desbaillets, I., Wenger, R.H., Neil, D.A.H., Bauer, C. Gassmann, M., Candinas, D., 2001. HIF-1 is expressed in normoxic tissue and 
displays an organ-specific regulation under systemic hypoxia. FASEB J. 15 2445-2453.

Susarellu, R., Fabioux, C., Sanchez, M.C., Le Goïc, N., Lembert, C., Soudant, P., Moraga, D., 2012. Molecular and cellular response to short-term oxygen variations in the Pacific oyster Crassostrea gigas. J. Exp. Mar. Biol. Ecol. 412, 87-95.

Tamura, K., Peterson, D., Peterson, N., Stecher, G., Nei, M., Kumar, S., 2011. MEGA5: molecular evolutionary genetics analysis using maximum likelihood, evolutionary distance, and maximum parsimony methods. Mol. Biol. Evol. 28, 2731-2739.

Tanner, C.A., Burnett, L.E., Burnett, K.G., 2006. The effects of hypoxia and pH on phenoloxidase activity in the Atlantic blue crab, Callinectes sapidus. Comp. Biochem. Physiol. A 144, 218-223.

Thetmeyer, H., Waller, U., Black, K.D., Inselmann, S., Rosenthal, H., 1999. Growth of European sea bass (Dicentrarchus labrax L.) under hypoxic and oscillating oxygen conditions. Aquaculture 174, 355-367.

Thomas, P., Rahman, S., 2009. Biomarkers of hypoxia exposure and reproductive function in Atlantic croaker: a review with some preliminary findings from the northern Gulf of Mexico hypoxic zone. J. Exp. Mar. Biol. Ecol. 381, S38-S50.

Weihe, E., 2009. Adaptation and stress defence in intertidal and subtidal Antarctic limpets (Nacella concinna): a study of the plasticity of molecular and biochemica stress response in Antarctic invertebrates (Doctoral Dissertation). Retrieved from depositddbde.
Wenger, R.H., 2000. Mammalian oxygen sensing, signalling and gene regulation. J. Exp. Biol. 203, 1253-1263.

Wenger, R.H., 2002. Cellular adaptation to hypoxia: $\mathrm{O}_{2}$-sensing protein hydroxylases, hypoxia-inducible transcription factors, and $\mathrm{O}_{2}$-regulated gene expression. FASEB J. 16, 1151-1162.

Wenger, R.H., Stiehl, D.P., Camenisch, G., 2005. Integration of oxygen signaling at the consensus HRE. Sci. STKE re12.

White, K.N., Ratcliffe, N.A., Rossa, M., 1985. The antibacterial activity of haemocyte clumps in the gills of the shore crab, Carcinus maenas. J. Mar. Biol. Assoc. UK 65, 857-870.

Whitworth, W.R., 1968. Effects of diurnal fluctuations of dissolved oxygen on the growth of brook trout. J. Fish. Res. Bd. Canada 25, 579-584.

Winn, R.N., Knott, D.M., 1992. An evaluation of the survival of experimental populations exposed t hypoxia in the Savannah River estuary. Mar. Ecol. Prog. Ser. 88, 161-179.

Wu, R.S.S., 2002. Hypoxia: from molecular responses to ecosystem responses. Mar. Pollut. Biol. 42, 35-45. 